\title{
Development of an integrated model for the Campaspe catchment: a tool to help improve understanding of the interaction between society, policy, farming decision, ecology, hydrology and climate
}

\author{
Takuya Iwanaga ${ }^{1}$, Fateme Zare ${ }^{1}$, Barry Croke ${ }^{1,2}$, Baihua Fu ${ }^{1}$, Wendy Merritt ${ }^{1}$, Daniel Partington ${ }^{3}$, \\ Jenifer Ticehurst ${ }^{1}$, and Anthony Jakeman ${ }^{1}$ \\ ${ }^{1}$ Fenner School of Environment and Society, Australian National University, Canberra, Australia \\ ${ }^{2}$ Mathematical Sciences Institute, Australian National University, Canberra, Australia \\ ${ }^{3}$ National Centre for Groundwater Research and Training, Flinders University, Adelaide, Australia
}

Correspondence: Barry Croke (barry.croke@anu.edu.au)

Received: 20 December 2017 - Revised: 23 January 2018 - Accepted: 3 February 2018 - Published: 5 June 2018

\begin{abstract}
Management of water resources requires understanding of the hydrology and hydrogeology, as well as the policy and human drivers and their impacts. This understanding requires relevant inputs from a wide range of disciplines, which will vary depending on the specific case study. One approach to gain understanding of the impact of climate and society on water resources is through the use of an integrated modelling process that engages stakeholders and experts in specifics of problem framing, co-design of the underpinning conceptual model, and discussion of the ensuing results. In this study, we have developed such an integrated modelling process for the Campaspe basin in northern Victoria, Australia. The numerical model built has a number of components:

- Node/link based surface water hydrology module based on the IHACRES rainfall-streamflow model

- Distributed groundwater model for the lower catchment (MODFLOW)

- Farm decision optimisation module (to determine irrigation requirements)

- Policy module (setting conditions on availability of water based on existing rules)

- Ecology module (determining the impacts of available streamflow on platypus, fish and river red gum trees)

The integrated model is component based and has been developed in Python, with the MODFLOW and surface water hydrology model run in external programs, controlled by the master program (in Python). The integrated model has been calibrated using historical data, with the intention of exploring the impact of various scenarios (future climate scenarios, different policy options, water management options) on the water resources. The scenarios were selected based on workshops with, and a social survey of, stakeholders in the basin regarding what would be socially acceptable and physically plausible options for changes in management. An example of such a change is the introduction of a managed aquifer recharge system to capture dam overflows, and store at least a portion of this in the aquifer, thereby increasing the groundwater resource as well as reducing the impact of existing pumping levels.
\end{abstract}




\section{Introduction}

Effective, and holistic, water management is contingent on understanding the stressors that affect water resources. Such stressors may come from a variety of physical and social (anthropogenic) sources. In the field of water resource management physical influences typically include the hydrology, geology, ecology/biology, and climatic processes. Social systems that influence and affect water management include agricultural enterprises, water policies, and the social factors that influence the acceptability of water use and management practices. Due to the complexity and interconnected nature of this system of systems, water resource managers and researchers often turn to integrated models to assess potential management actions within the specific context.

Managing such system of systems requires the consideration of a wide range of factors across the interconnected physical and social domains. Integrated Assessment (IA) should not be conducted by individual disciplines in isolation as the issues faced do not fall neatly into traditional academic disciplines. Each represented system may have differing problem frames which influence and affect each other due to the interconnected nature of socio-enviro systems. Therefore, the development of Integrated Assessment Models (IAM) should not be conducted by model developers alone but in conjunction with experts and stakeholders so that the specifics of the problem frame(s) are accounted for. Collectively these problem frames make up a management context, a term used here to refer to the physical properties, the social elements and activities that have influence, and the management scope and objectives of concern.

The lower Campaspe basin in the north-central region of Victoria, Australia is an example of a highly interconnected socio-enviro system. We describe herein an iterative integrative process used to develop an Integrated Assessment Model (IAM) suited for the specific management context. Model development was continuously informed by stakeholder and expert knowledge throughout the process from initial conceptualization through to completion. As new information and knowledge became available and challenges encountered, stakeholders and experts were re-engaged to update the problem frames and model design; a beneficial co-design process. Incorporation of feedback at each iterative stage then helps to ensure that the model remains relevant for its given purpose and to the stakeholders themselves.

The principal aim of the model is to inform stakeholders of the impacts of a range of possible combinatory policy and on-farm water management decisions under a variety of climate conditions. These collectively represent a set of possible "futures". The model will be used in an exploratory manner through which a multitude of such possible "futures" are generated. The combination of factors that led to positive (or at least effective compromises) and negative future conditions can then be identified and communicated to stakeholders through this exploratory process. Because the geophysi- cal, geographical, and social elements are found in a range of contexts, this iterative process is a generally applicable integrative water management approach.

\section{Management context}

Defining the management context through systems analysis with the aid of stakeholder knowledge is a crucial first step in an integrated assessment process, and a key aspect of Integrated Assessment Modelling (IAM, as in Jakeman and Letcher, 2003). Kraft et al. (2010) argues the importance of stakeholder involvement as incorporation of local domain knowledge ensures that key features of the management context are captured and subsequently represented in the model. Stakeholders further represent an important source of local knowledge which may in turn drive both information need and data accessibility, as well as playing an important role in validating model outputs (Krueger et al., 2012).

The involvement of stakeholders increases the transparency of the development process as it is exposed for critique and review by stakeholders. Through this stakeholder engagement process the scope and objectives of the model can be iteratively developed and refined so that the final model is suitable and relevant (and therefore useful) for the end purpose and users (Jakeman and Letcher, 2003). The process for gathering information and knowledge of the management context and the subsequent influences and implications on the model design and approach is described in later sections.

One motivation for this study was the adoption of the Murray-Darling Basin Plan developed under the Australian Government Water Act 2007. The Basin Plan defines environmental objectives which includes increasing water availability for the environment. To this end the Basin Plan sets Sustainable Diversion Limits, which will be applicable from 1 July 2019 for both ground and surface water (NCCMA, 2014a).

\subsection{The Lower Campaspe}

The Lower Campaspe catchment covers the northern portion of the Campaspe catchment in North-Central Victoria, an area that is approximately $150 \mathrm{~km}$ long and $25 \mathrm{~km}$ wide (NCCMA, 2014b), and is itself a part of the Murray-Darling Basin. The Campaspe River starts from the Great Dividing Range in the south, flowing in a northerly direction into Lake Eppalock from which the Lower Campaspe River begins. The Lower Campaspe River then continues northwards (downstream) into the Murray River which flows in a westerly direction. Population centres along the Lower Campaspe River include (from south to north) Axedale, Barnadown, Elmore, Rochester, and Echuca. The Lower Campaspe River itself is highly regulated by the operation of a dam at Lake Eppalock, the Campaspe Weir and Siphon located north of 


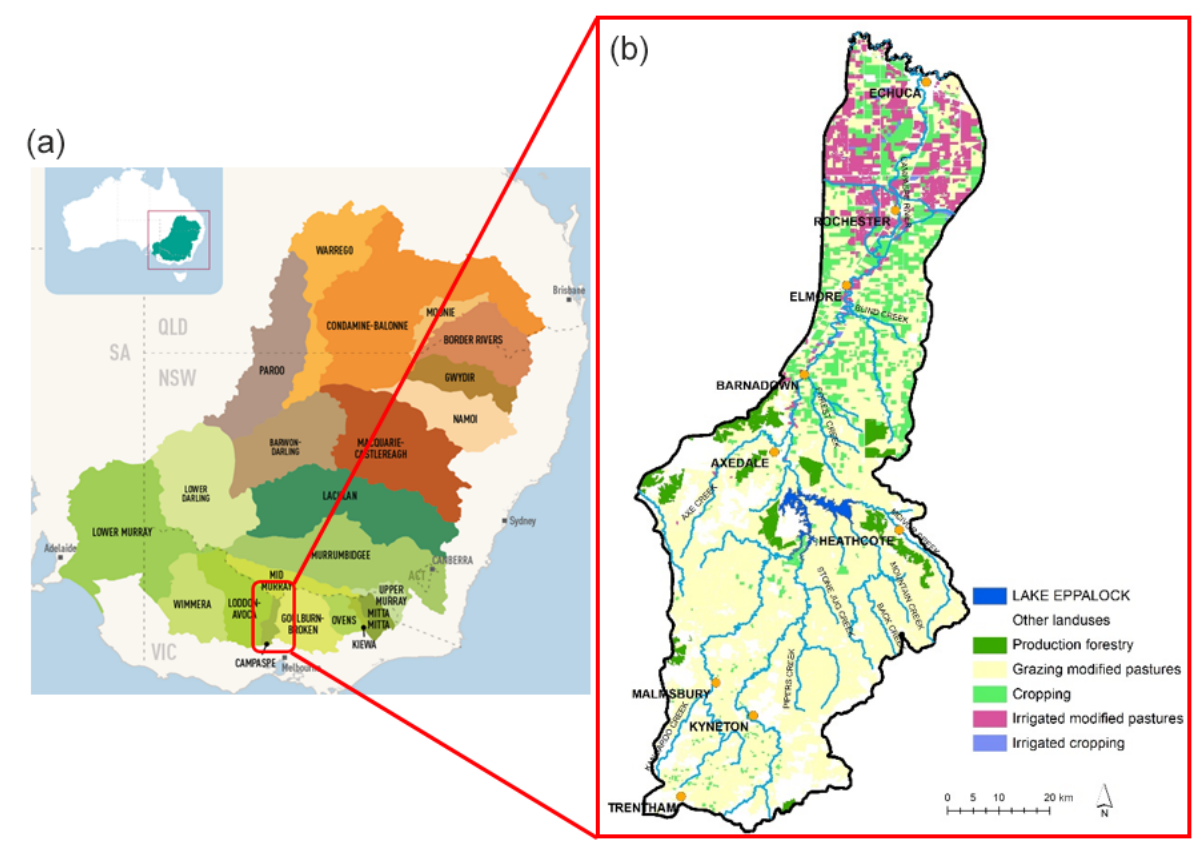

Figure 1. Panel (a) depicts the Campaspe catchment in the Murray-Darling Basin (adapted from MDBA, 2017) while (b) shows the Campaspe catchment proper with land use in the region.

Rochester (NCCMA, 2014b). A map indicating the catchment location is shown in Fig. 1.

\section{Climate}

The lower Campaspe is reported to be a dry semi-arid area which is evident in the historic rainfall records, with the median yearly rainfall being $434 \mathrm{~mm}$ (see Fig. 2). Two notable dry periods are identifiable in the historic rainfall records for the past 30 years which have influenced irrigators and water management. The first is a severe drought that occurred during 1982/1983 during which almost no rainfall occurred during the growing season resulting in severe (wheat) crop loss across eastern Australia (ABS, 1988; Arad and Evans, 1987; BoM, 2009). The second was the millennium drought, described as the worst drought on record for southeast Australia, defined as starting in 2001 with the drought eventually broken in 2009 (Van Dijk et al., 2013).

Climate projections for Northern Victoria, of which the Campaspe catchment is a part of, describe drier conditions with rainfall expected to decrease compared to the historic 20 -year average. Decreases in mean rainfall of $12-13 \%$ across south and east Australia compared to the 100-year average (1900-2000) have already been experienced within the first decade of the new millennium (2001 to 2009, Van Dijk et al., 2013).

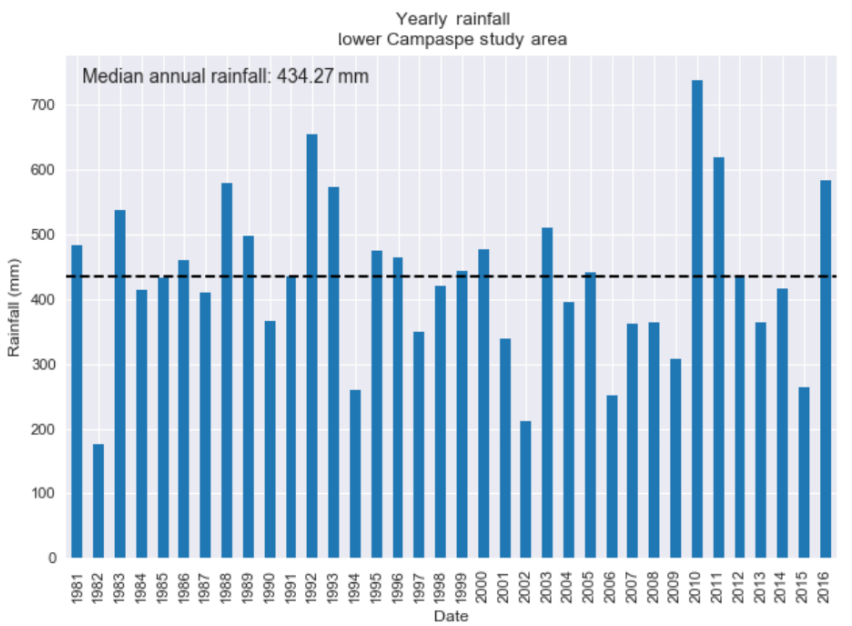

Figure 2. Yearly rainfall in the Lower Campaspe study area. The median amount was found to be $434 \mathrm{~mm} \mathrm{yr}^{-1}$ (indicated by the dashed black line).

\subsection{Hydrology}

The area of the Campaspe basin is $4179 \mathrm{~km}^{2}$, with a river length of $220 \mathrm{~km}$, and a mean annual streamflow volume of $352 \mathrm{GL}$. The elevation in the southern part of the basin is around $600 \mathrm{~m}$ AHD (Australian Height Datum), with mean annual rainfall up to $1000 \mathrm{~mm}$, and estimated mean annual pan evaporation of approximately $1300 \mathrm{~mm}$. Near the catchment outlet (elevation $98 \mathrm{~m} \mathrm{AHD),} \mathrm{the} \mathrm{mean} \mathrm{annual} \mathrm{rainfall}$ is approximately $430 \mathrm{~mm}$, while the estimated mean annual 
pan evaporation is approximately $1700 \mathrm{~mm}$. The main storage in the basin is Lake Eppalock, which has a catchment area of $2124 \mathrm{~km}^{2}$, a storage capacity of $304 \mathrm{GL}$, and is located about $135 \mathrm{~km}$ from the catchment outlet at an elevation of about $160 \mathrm{~m}$ AHD. A further 3 large storages are located on the Coliban River (upstream of Lake Eppalock), with a total storage of 70 GL (BoM, 2017; GM-W, 2017a, b; MDBA, 2017).

\subsection{Hydrogeology}

The Campaspe region comprises the recent Coonambidgal Formation incised by the Campaspe River through the Shepparton formation, Parilla/Loxton sands, Newer Volcanic Basalts, with the primary productive aquifers of the region in the Calivil Formation and Renmark Group (collectively known as the Deep Lead)which overlay the Palaeozoic bedrock. The majority of the lower Campaspe consists of the Shepparton formation and the Deep Lead. The Deep Lead aquifers are the primary source of groundwater in the lower Campaspe irrigation areas, in which the Shepparton Formation has low permeability and is not very transmissive. Further details of the local hydrogeology may be found in Chiew et al. (1995).

\subsection{Stakeholders}

The local water corporation, Goulburn-Murray Water (GM Water), manages both surface and groundwater resources in the Lower Campaspe. Management includes the operation of the dam, water delivery infrastructure maintenance and investment, and the water accounts and licences in the region. GM Water is additionally responsible for determining the amount of water allocations - a percentage of water that an irrigator is entitled to - during each irrigation season.

The Department of Economic Development, Jobs, Transport and Resources (EcoDev) is a state level Government department that is interested in the water resource management and policy aspects, as well as providing advice and assistance to farmers regarding on-farm activities. The North Central Catchment Authority (NCCMA) and an expert from the Australian Platypus Conservancy were engaged for their input and feedback on the ecological system. Farmers themselves are an important stakeholder group to include as they will be impacted by any policy and climatic changes as well as being an important influencer of ecological and recreational water availability. Recreational users of the reservoir at Lake Eppalock were involved due to concerns that over-allocation of water for agricultural purposes have, and will exacerbate, negative impacts on recreational activities.

To gain further insights into the socio-agricultural system Ticehurst and Curtis $(2016,2017)$ conducted a survey of irrigators during 2016. The survey gathered responses from 254 participants (of 754 surveys sent out) that were later determined to be representative of irrigators in the region. The findings relevant to the model development process are repeated here, however readers are directed to Ticehurst and Curtis $(2016,2017)$ for further detail on the survey process.

These stakeholder groups were all engaged with through a series of workshops and discussions from late 2015 onwards. The latest workshop was run in October 2017, and another scheduled for March 2018. These stakeholder engagement activities aided in the selection of scenarios which describe plausible, and socially acceptable, options for changes in water management. Examples of such scenarios include the introduction of a managed aquifer recharge system to capture dam overflows for storage in the aquifer for use in times of water scarcity. Recharging the groundwater resource in this manner increases the availability of groundwater as well as reducing the impact of existing pumping levels.

\section{Modelling process}

The model development process followed a participatory process in which multi-disciplinary practitioners engaged with stakeholders. Through this process the model and its purpose was collaboratively defined and developed. Stakeholders play an additional important role in the development of scenarios of interest and validating model scope and behaviour (Krueger et al., 2012). Participatory engagement elicited a key set of management objectives including holistic management of water resources to improve crop yields, reliability of water availability, and beneficial improvements to environmental and socio-economic outcomes. Inclusion of stakeholders in the design and development process additionally fosters trust between stakeholders and modellers, and as a consequence model results (Franzén et al., 2011).

Another perspective is that of a software developer, as model implementations will largely be expressed in computer code. It is perhaps of interest to note that both software and model development best practices suggest an iterative process and arrived at these processes seemingly independently of each other. Sletholt et al. (2012) for example details and identifies software development practices that can be found in the model development process that have direct counterparts to software development practices.

A key point of interest is that iterative development is regarded as best practice in both model and software development paradigms. From a model developers' perspective continuous engagement with stakeholders has a hand in early detection and correction of faulty assumptions (Jakeman et al., 2006). Continuous exposure to the development process and incorporating feedback can drive stakeholder acceptance of the model by ensuring that the modelling process is transparent and relevant (Chan et al., 2010; Voinov and Gaddis, 2008). Jakeman et al. (2006) suggest an iterative approach to model development, where progress is reviewed at various steps, and part of the process repeated if issues are found. For software developers, iterative processes enable continu- 


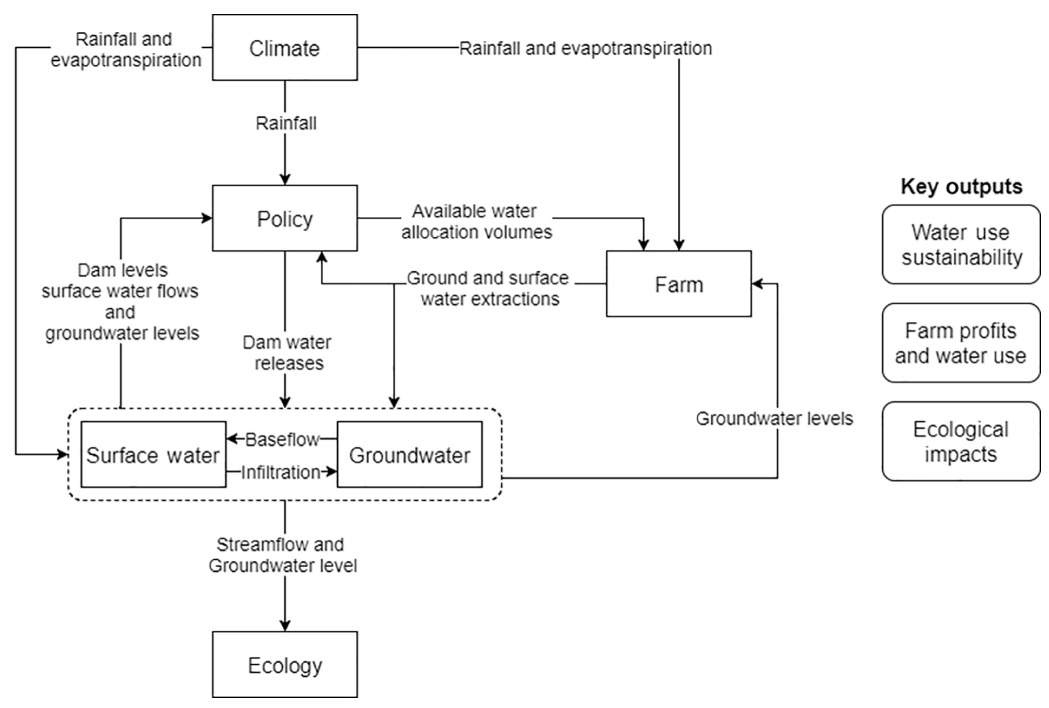

Figure 3. The interactions between component models and key model outputs. The dashed box around surface and groundwater models was inserted to simplify the model diagram and is not intended to indicate a separate coupled model.

ous validation of model implementation and the adjustments necessary to incorporate stakeholder feedback (Sletholt et al., 2012). To this end a component-based approach was applied for the implementation of the model, and so the development process could be described as applying a component-based participatory approach.

Component-based approaches compose a collection of compartmentalized models coupled loosely through a common framework. Loose coupling is achieved using specifically defined interfaces which handle data exchange and refers to the fact that the connections, and thus the feedbacks, between models are no longer "hardwired" to specific models. Malard et al. (2017) refers to the use of interfaces as a "wrapper approach" wherein the individual component models are "wrapped" and interactions channelled through the interfaces. Benefits of such an approach include the ability to reuse or "swap" a given component model for another (either new or pre-existing) as the need arises (de Kok et al., 2015). Changes within a model that do not affect the interface (i.e. the inputs and outputs) are safely abstracted and as such do not propagate and affect other component models. Incorporation of stakeholder feedback then becomes less problematic due to this model compartmentalization allowing model developers to focus on the modelling process instead of issues that may arise from direct coupling. Expected behaviour can then be verified through testing and comparisons against previous model outputs. As a consequence modellers are then able to progress through the iterative loops at a faster pace.

\section{Model framing}

To support these water reforms Federal and State Governments invested heavily in a modernization program in 2007
(State of Victoria, 2011), what is now known as the Connections Project and managed by GM Water. This infrastructure investment was described as the largest investment in irrigation infrastructure by the Australian Government (a total of AUD 1.1 Billion as reported in Bowler, 2015). A primary aim of the Connections Project was to improve the efficiency of water delivery and on-farm water use to meet sustainable water use goals as defined in the national Murray-Darling Basin Plan introduced in 2012 (Bowler, 2015).

Conjunctive use of water resources were identified by Ticehurst and Curtis (2017) as one method of improving water availability in the catchment. Here conjunctive water use was broadly defined as the multi-use of water sourced from both surface and groundwater for agricultural, recreational, and environmental purposes.

\section{Model components}

Each component represents a system of interest which collectively describes a system of systems. The developed integrated model represents a sociohydrological-environmental system including a farm model, surface water representing the lower Campaspe River and tributaries, groundwater hydrology, and a water management policy model. A climate component is also included which serves to provide the necessary rainfall and evapotranspiration data at the requisite spatial and temporal scales. The component models are coupled through a common framework developed in the Python programming language. Component models are not required to be developed in the same language as the framework as Python has robust language interoperability capabilities. The interactions between component models through their interfaces are depicted in Fig. 3. 


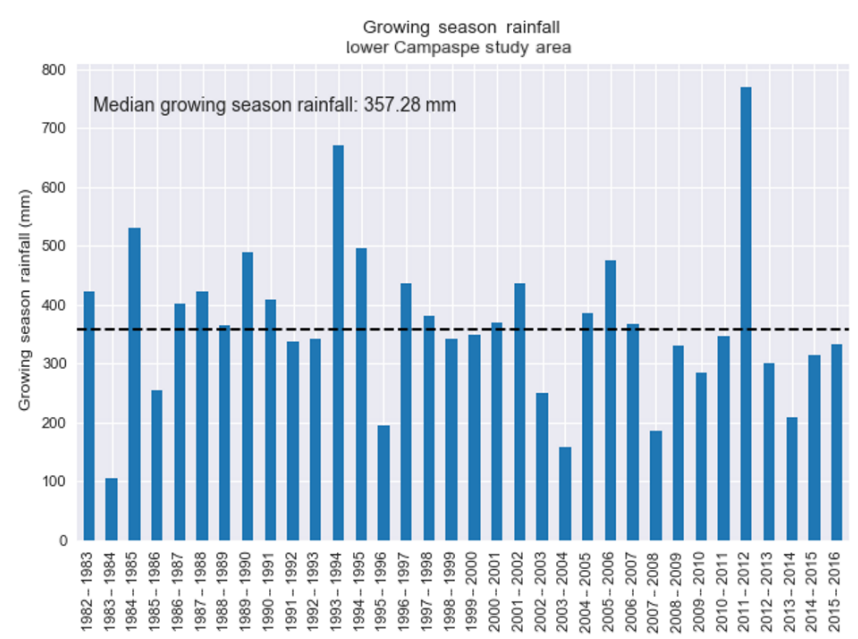

Figure 4. Growing season rainfall over the 1982-2015 growing seasons. Median growing season (dashed black line) was found to be $357.28 \mathrm{~mm}$, below the usual growing season rainfall of $420 \mathrm{~mm}$ (see Fig. 5 below).

In this section examples of the implications and influences from stakeholder feedback on each of the component models are given. The model continues to be developed in light of findings described herein, and as such is not made publicly available, although public release is intended. Additionally the data comes from various sources and so possible issues regarding intellectual property and data ownership will have to be cleared before public availability is possible. Model development utilizes version control which allows for the release of the model (in its current and future state) and requisite data at a later date.

\subsection{Climate}

Ticehurst and Curtis (2016) found that over $80 \%$ of farmers surveyed believed that the impact of drought and changing rainfall patterns were important or very important. This finding in conjunction with the observed decrease in rainfall (see Sect. 2.1.1) shows that it is necessary to consider the impact of further climate variability. To this end (30 year) historic and future climate data were sourced via Climate Change in Australia (https://www.climatechangeinaustralia. gov.au, CSIRO, 2017). These datasets are described as being application ready. Long term ( $\sim 100$ years) climate records were developed through the use of interpolated historic rainfall and pan evapotranspiration data (see Vaze et al., 2011). The recent decrease in rainfall is evident within a typical growing season (defined as May to February). The median in-season rainfall during 1982 to 2016 was found to be $357 \mathrm{~mm}$ (see Fig. 4), compared to the reported usual growing season rainfall of 400 to $500 \mathrm{~mm}$ (EcoDev, 2015) and as indicated in the long term growing season rainfall records (see Fig. 5).

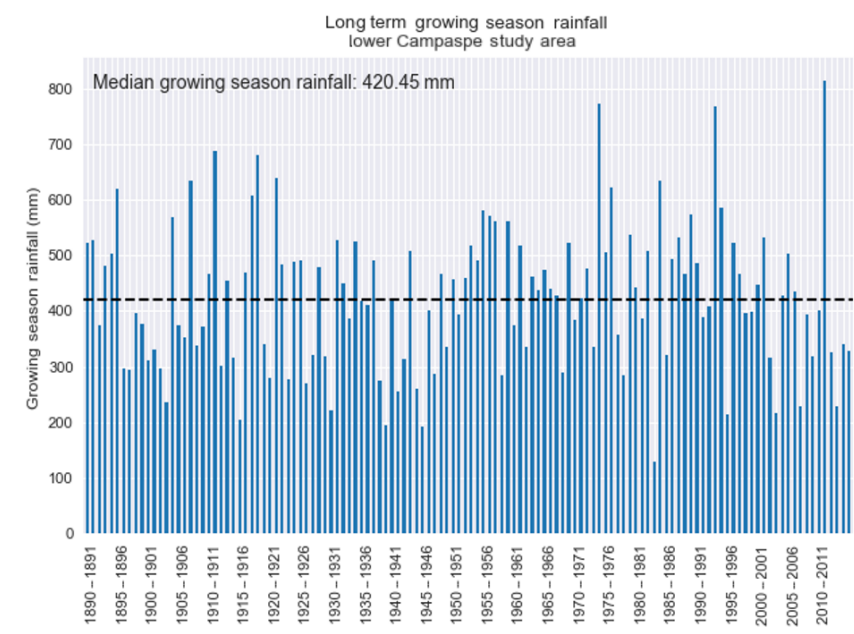

Figure 5. Long term growing season rainfall. Median in-season rainfall was found to be $420.45 \mathrm{~mm}$ (dashed black line).

\subsection{Surface water}

The surface water module estimates the flows and water levels at selected nodes in the Campaspe Catchment. The nodes have been selected based on the location of gauges with suitable data, taking into consideration the needs of the integrated model (Fig. 6). As the focus of the integrated model is the lower Campaspe Catchment (below Lake Eppalock), the majority of the nodes are located in that region. To model the surface water flows, this means having information on releases and spills from Lake Eppalock, thereby requiring an estimate of the inflows to the reservoir. The resulting nodes are shown in Fig. 7. The surface water flows also depend on interaction with the groundwater, requiring a comparison of surface water levels with groundwater levels. This means that the surface water module needs to estimate the surface water levels at the nodes, and that this information is passed to the groundwater model in order to estimate the infiltration loss/baseflow contribution to surface water flow.

The surface water module has three components: a rainfall-streamflow model, a routing module and a rating curve module. Inputs required by the model are climate data (rainfall and potential evaporation), as well as estimates of the groundwater/surface water interactions (from the groundwater module), releases from Lake Eppalock reservoir (from the policy and the farm modules) and extractions from the surface water flows (from the farm model).

The rainfall-streamflow model used here is a variant of the IHACRES model, incorporating a non-linear loss module which converts rainfall into effective rainfall (rainfall that contributes to streamflow), and a unit hydrograph module that represents the dynamics of the water moving through the catchment (river network and landscape). The non-linear loss module used is based on the CMD version of the non-linear module (Croke and Jakeman, 2004), modified to produce two inputs to the unit hydrograph module (Croke et al., 2015): a 


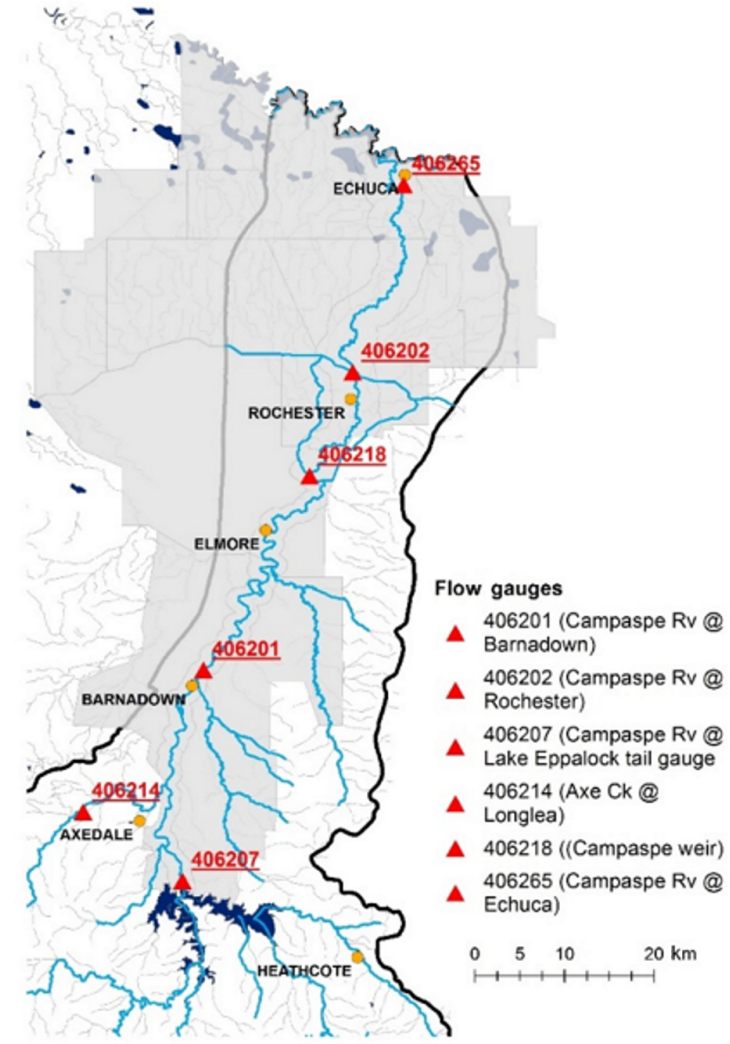

Figure 6. Flow gauges in the lower Campaspe.

contribution to the quick flow component $\left(u_{k}\right)$ and a contribution to the slow flow component $\left(r_{k}\right)$. This permits the model to partition effective rainfall between the two components based on the modelled catchment moisture status. The unit hydrograph module comprises two exponentially decaying stores arranged in parallel (a quick and a slow flow component), modified from the original to take the inputs to each store directly from the CMD module outputs.

An exponentially decaying store is also used to route the flows between nodes (a lag-route approach, Croke et al., 2006). In both the routing and the rainfall-streamflow models, the impact of losses from the river network are taken into consideration using the approach of Ivkovic et al. (2014). The rating module makes use of the rating curve data available at most gauge sites (the exception is gauge 406218, where only water level data is available).

\subsection{Groundwater}

The groundwater flow module is used to estimate the surface water-groundwater exchanges along the Campaspe River between flow gauges, and to provide information on the groundwater levels at specific locations as well as groundwater levels averaged over larger areas. The groundwater flow module interacts with the hydrology, farm, ecology and policy modules as detailed in Fig. 7.

The first stakeholder engagement workshop and subsequent communication with stakeholders (in particular, a local hydrogeologist) led to the definition of the groundwater model boundary, delineation of the hydrogeological units and provision of input data for groundwater pumping as well as observational head and chemistry data. Defining the model boundaries through this engagement ensured that the area covered as well as representation of hydrogeological units was consistent with their interpretation of the system and met the requirements for areas of interest. Furthermore the boundary conditions used came out of this initial consultation, in particular the consideration of the Campaspe River and smaller inflowing tributaries, the latter of which are not represented in the groundwater model due to their ephemeral nature and low flows.

The groundwater flow model of the Lower Campaspe Valley region is a finite difference representation. The model was constructed with Python scripts utilising Flopy (Bakker et al., 2016), and uses MODFLOW NWT (Niswonger et al., 2011). Representation of the hydrogeologic units (HGUs) is based on rasters ( $100 \mathrm{~m}$ resolution) from the Victorian Aquifer Framework (DSE, 2012). The model is made up of 7 layers, with a horizontal resolution of $1 \mathrm{~km}$, and vertical spacing of the model grid informed by the HGU rasters. The $5 \mathrm{~km}$ resolution was chosen for computational speed to avoid the groundwater model becoming a computational bottleneck for the integrated model. Some HGUs span multiple layers where they are not overlain by other HGUs. There are 41209 active cells within the model.

The groundwater model is driven by rainfall, river stage, groundwater extraction via pumping wells and groundwater head data via a series of boundary conditions shown in Fig. 7. Recharge in the model is implemented in the top layer of the model with the RCH package, and is calculated as a reduction of rainfall using a rainfall reduction parameter, and as such evapotranspiration is not directly modelled. River boundary conditions are implemented using the RIV package for the Campaspe River and Murray River. To allow outflow below the Murray River, through the subsurface in the north of the catchment, a general head boundary condition is implemented with the GHB package.

The model was calibrated using PEST (Doherty, 2016) to groundwater head data by modifying the HGU properties (i.e. hydraulic conductivity, specific yield and specific storage) and also a rainfall reduction parameter, applied statically from the period 1966-2015 and based on monthly stress periods. Initial conditions for the model were established by running the model in steady-state using long-term average rainfall and river stages.

As depicted in Fig. 7, the groundwater model is forced by: 

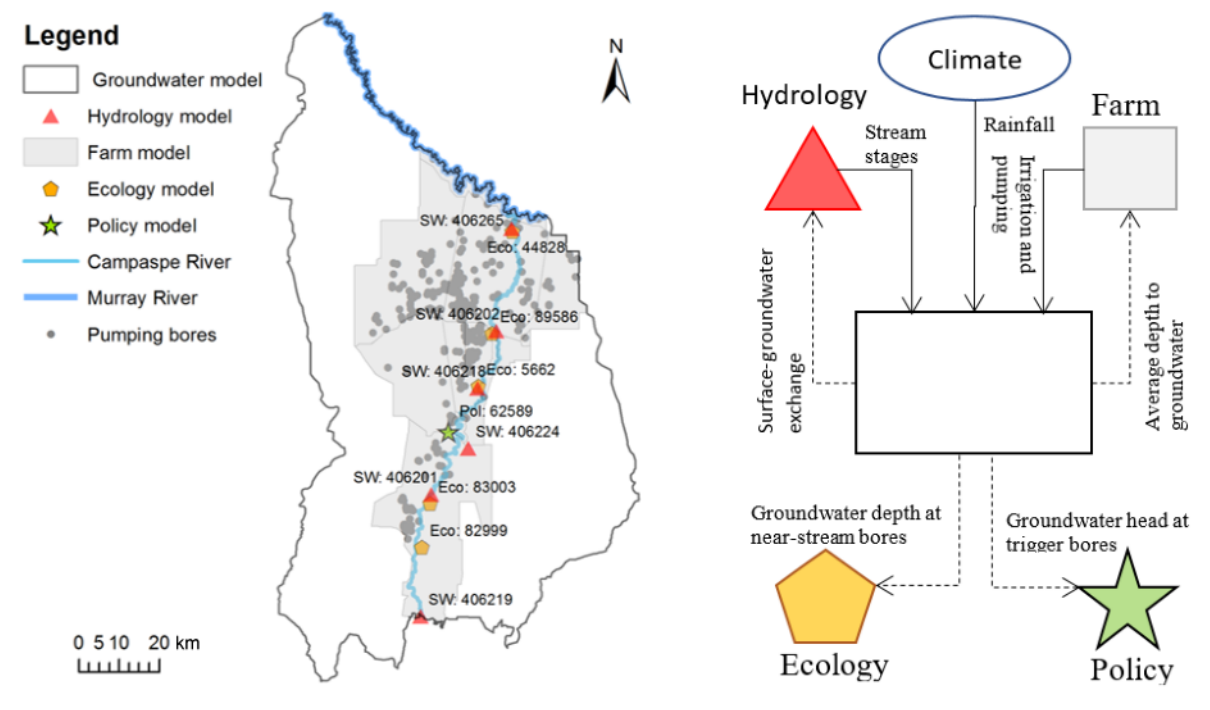

Figure 7. Groundwater model components and model area as well as points and interactions with other component models from the perspective of the groundwater model.

- Distributed rainfall (to be reduced through the rainfall reduction parameter) and irrigation water from the Farm model;

- Pumping volume from the Farm model (uniformly applied across pumps in the area);

- River stages from the Hydrology model

- After running each daily time-step, the model returns the:

- Surface water-groundwater exchange along reaches of the river consistent with the Hydrology model

- the average depth to groundwater for the Farm model

- depth to groundwater at key sites dictated by the Ecology model

- groundwater head at trigger level bores as dictated by the Policy model

Increases and decreases to pumping driven by the Farm model were applied to relevant wells within each farm zone. Surface water-groundwater responses lag behind the surface water forcing from the Hydrology model due to the use of a sequential coupling; it was assumed that a daily lag would not create significant differences in model behaviour. Outputs from the groundwater model, while not precise at the scale of local wells due to model resolution, were fit for purpose for indicative average groundwater levels at points of interest. In the case of the Ecology model, this is subject to the most variability as the levels are near-stream where the depth to groundwater table can change rapidly as it converges to the river. For the Policy model the trigger bores are chosen to be indicative of larger scale behaviour and hence the use of the average head in cells that correspond with the trigger bores is deemed adequate.

\subsection{Policy}

The current policy setting in the Campaspe is quite sophisticated reflecting extensive water reforms which introduced water trading, carryover, and environmental water provisions (Alston and Whittenbury, 2011; McKay, 2005; Wheeler and Cheeseman, 2013). The policy component of the integrated model provides a representation of policies determining the water allocation and carryover for entitlement holders (farm and environment). Use of these policies as a scenario supports further investigation of the implications and viability, as well as the opportunities, of the given policy condition(s) in the context of climate variability. The design of the policy component was such that it would allow scenarios that fit with current policies (e.g. increased groundwater use) but also the capability to explore alternate policy futures (e.g. conjunctive management of surface and groundwater, Managed Aquifer Recharge, and inter-catchment transfers). The latter include some of the conjunctive use opportunities explicitly identified with Campaspe stakeholders. For example, groundwater and surface water are managed separately in the current policy space. One option identified with Campaspe stakeholders was the temporary relaxation of groundwater restriction trigger levels during dry times when surface water allocations are low, with compensatory actions to increase recharge when climate conditions improve.

Within the current policy setting, groundwater use can be increased as most irrigators surveyed in the region are primarily reliant on surface water resources. Reported figures include $91 \%$ of irrigators holding surface water licences 
compared to $22 \%$ that additionally hold groundwater licences. Groundwater use historically reach a maximum of $60 \%$ of allocated volumes, although this has increased to $80 \%$ in recent times (2016 water usage, reported in Ticehurst and Curtis, 2017).

\subsection{Farming}

The farm component was developed with the aim of enabling investigation into the effect of water policy and water availability on farm financial performance under variable climate scenarios. Key attributes that are represented include the crop - currently one of wheat, barley or canola and tomato - irrigation system, pumping systems and soil types. The farming system is represented in a lumped manner with the study area divided into 12 zones configured to represent a mix of applicable surface and groundwater policy, water entitlements and usual cropping practices.

The principal agricultural enterprise in the Lower Campaspe is dairy farming with $55 \%$ of land use devoted to annual and perennial pastures, $70 \%$ (i.e. $38.5 \%$ of reported farming area) of which is irrigated. Cereal cropping amounted to $35.8 \%$ of land use, although the majority of this (68\%, i.e. $\sim 24 \%$ of reported farming area) is dryland. Dairy farming is to be represented in the model through the use of an indicator crop to represent annual and perennial pasture crops and discussions with local experts are ongoing to determine how best to implement this.

Historically, the Campaspe region was an irrigation intensive area however most irrigators $(90 \%$, concentrated in the middle of the study area) stopped irrigation practices in 2010 (NVIRP, 2010). This exit occurred during the millennium drought period (2001-2009) during which irrigators' water allocations were significantly reduced (NCCMA, 2014a). Irrigation is currently concentrated in the lower portion of the catchment the northern area surrounding Echuca, with dryland cropping in the mid and upper areas. A return to irrigation practices in the future remains a possibility due to the network of accessible irrigation infrastructure modernized under the Connections Project.

In the North Central region flood irrigation is the most common irrigation system in use accounting for $99 \%$ of irrigated area (Ash, 2006). Flood irrigation is said to be 50-80\% water use efficient, meaning that 50-20\% of water applied to the field is lost (Clemmens, 2000; Finger and Morris, 2005; Tennakoon et al., 2013). Of those surveyed $77 \%$ of respondents reported having undertaken additional improvements to flood irrigation such as laser grading and tail-water reuse, increasing the water use efficiency. Flood irrigation was then modelled as being $70 \%$ water use efficiency based on this information. Other improvements can be achieved through the adoption of a piped system or investing in spray irrigation which is said to be $80 \%$ water use efficient (Clemmens, 2000; Finger and Morris, 2005).
Outside of the survey, further information was gained through stakeholder engagement. It was highlighted, for example, that the choice to invest in a more water efficient irrigation system depends on the soil type. As such, generating a suitable representation of the soil textures in the modelled farming zones becomes a necessity and acts as a constraint to the choice of irrigation system adopted at each zone. It was also initially assumed that the vast majority of pumping systems in the area were diesel based rather than electric due to the substantial capital costs involved in developing the necessary infrastructure to operate electric pumps. This assumption was also corrected with local knowledge - electric pumping is in reality quite common and is used over the weekends due to off-peak electricity prices. The model will be modified to incorporate this elicited information.

\subsection{Ecology}

Management decisions that affect the lower Campaspe ecosystems flow on to the Murray River as the Campaspe flows into the Murray. The local ecology has historically been neglected due to over allocation of water resources for agricultural purposes. Decline in riverine health have been reported over the years including substantial decreases in biodiversity (MDBA, 2012; NCCMA, 2014b). The MurrayDarling Basin Plan includes provisions for increased environmental flows to support ecosystem maintenance and recovery (Bowler, 2015; GM-W, 2013; Hughes et al., 2015), and to meet these obligations up to $75 \mathrm{GL}$ of water savings through infrastructure improvements through the GM Water Connections Project (formerly NVIRP) were intended for environmental purposes (NVIRP, 2011).

The local ecology along the Lower Campaspe River include communities of River Red Gum, a eucalyptus tree that is considered iconic (NCCMA, 2014b), platypus colonies, and two native fish populations: the Murray Cod and Golden Perch. Conceptualization and design of the model incorporated feedback from ecology experts from the NCCMA and the Australian Platypus Conservancy. Stakeholder feedback in combination with prior ecological studies and data availability resulted in the development of methods to generate indices that indicate the suitability of water flow for these flora and fauna. These consist of three indices for the River Red Gum which represent the suitability of groundwater availability and surface water flows for the maintenance and regeneration of the iconic tree. The fish indices capture key flow requirements as recommended in the Campaspe River Environmental Water Management Plan (NCCMA, 2014a). Indices developed for platypi indicate flow conditions that sustain food supply and movement, breeding cycles, and the avoidance of burrow flooding during the mating season. 


\section{Conclusion}

Both model and software development best practices recommend working within an iterative cycle that moves the project towards a continually (re)defined goal, informed by stakeholders. Including stakeholders in the iterative development of integrated models was found to be useful in ensuring model validity, relevance, transparency and acceptability. Participatory engagement acts as a peer review process within each iteration of the model development cycle whilst also fostering trust between all participants, modellers and stakeholders alike.

Component-based development processes were found to be complementary to the participatory modelling approach. Throughout each iteration the implementation of the described component models were influenced by stakeholder knowledge and information. The compartmentalization of models that collectively represent a system of systems disentangles their implementation allowing specific and targeted modifications based on stakeholder feedback. Such changes then do not propagate throughout the model as a whole, allowing modellers to progress through each iteration quicker whilst simultaneously ensuring that the model development process is transparent.

Data availability. Climate time series data presented here is available from the Australian Bureau of Meteorology http://www.bom. gov.au/.

Competing interests. The authors declare that they have no conflict of interest.

Special issue statement. This article is part of the special issue "Innovative water resources management - understanding and balancing interactions between humankind and nature". It is a result of the 8th International Water Resources Management Conference of ICWRS, Beijing, China, 13-15 June 2018.

Acknowledgements. The primary author is supported through an Australian Government Research Training Program (RTP) Scholarship. The work was carried out as part of the MurrayDarling Basin Authority's partnership with the National Centre for Groundwater Research and Training (NCGRT). The authors would like to thank representatives from Goulburn-Murray Water and the Victorian Department of Economic Development, Jobs, Transport and Resources for their valuable insights and assistance over the course of this work. The authors would like to additionally thank the reviewers for their valuable comments and suggestions to improve the quality of this paper.

Edited by: Dingzhi Peng

Reviewed by: Qinglan Li and one anonymous referee
References

ABS: Drought in Australia, available at: http://www.abs.gov.au/ausstats/abs@.nsf/0/ 068F13BCCD03F27BCA2569DE001F1072?OpenDocument (last access: 26 February 2018), 1988.

Alston, M. and Whittenbury, K.: Climate change and water policy in Australia's irrigation areas: a lost opportunity for a partnership model of governance, Environ. Polit., 20, 899-917, https://doi.org/10.1080/09644016.2011.617175, 2011.

Arad, A. and Evans, R.: The hydrogeology, hydrochemistry and environmental isotopes of the Campaspe River aquifer system, North-Central Victoria, Australia, J. Hydrol., 95, 63-86, https://doi.org/10.1016/0022-1694(87)90116-8, 1987.

Ash, L.: Irrigation Farm Survey 2004/2005 Summary Extract from the final document 17/10/06, NSW Department of Primary Industries, Sydney, Australia, 2006.

Bakker, M., Post, V., Langevin, C. D., Hughes, J. D., White, J. T., Starn, J. J., and Fienen, M. N.: Scripting MODFLOW Model Development Using Python and FloPy, Groundwater, 54, 733-739, 2016.

BoM: Western Australia to the Rescue, avaiable at: http://pandora.nla.gov.au/pan/96122/20090317-1643/www. bom.gov.au/lam/climate/levelthree/c20thc/flip4.html (last access: 11 May 2016), 2009.

BoM: Climate and past weather information, available at: http: //www.bom.gov.au/climate/ (last access: 18 December 2017), 2017.

Bowler, M.: Report for the Department of Agriculture and Water Resources - Goulburn-Murray Water Connections Project Stage 2 - Mid Term Review, GHD, Melbourne, Victoria, Australia, 2015.

Chan, T., Ross, H., Hoverman, S., and Powell, B.: Participatory development of a Bayesian network model for catchment-based water resource management, Water Resour. Res., 46, W07544, https://doi.org/10.1029/2009WR008848, 2010.

Chiew, F. H. S., McMahon, T. A., Dudding, M., and Brinkley, A. J.: Technical and economic evaluation of the conjunctive use of surface and groundwater in the Campaspe Valley, northcentral Victoria, Australia, Water Resour. Manage., 9, 251-275, https://doi.org/10.1007/BF00872487, 1995.

Clemmens, A. J.: Measuring and improving irrigation system performance at the field level, in: Connellan, G. J., Irrigation Association of Australia 2000 National Conference and Exhibition: Water - Essential for Life. Proceedings. Melbourne Exhibition and Convention Centre, 23-25 May 2000, Irrigation Association of Australia, Melbourne, 190-199, 2000.

Croke, B. F. W. and Jakeman, A. J.: A Catchment Moisture Deficit module for the IHACRES rainfall-runoff model, Environ. Modell. Softw., 19, 1-5, 2004.

Croke, B. F. W., Letcher, R. A., and Jakeman, A. J.: Development of a flow network for the Namoi River Basin, Australia, J. Hydrol., 319, 51-71, https://doi.org/10.1016/j.jhydrol.2005.07.001, 2006.

Croke, B., Cornish, P., and Islam, A.: Modeling the Impact of Watershed Development on Water Resources in India, in: Integrated Assessment of Scale Impacts on Watershed Intervention: Assessing Hydrogeological and Bio-physical Influences on Livelihoods, edited by: Reddy, V. R. and Syme, G. J., Elsevier, 100$148,2015$. 
CSIRO: Climate Change in Australia, available at: https://www. climatechangeinaustralia.gov.au/en/ (last access: 13 December 2017), 2017.

de Kok, J. L., Engelen, G., and Maes, J.: Reusability of model components for environmental simulation Case studies for integrated coastal zone management, Environmental Modelling and Software, 68, 42-54, https://doi.org/10.1016/j.envsoft.2015.02.001, 2015.

Doherty, J. E.: PEST, SENSAN and Global Optimisers, in: PEST, Model-Independent Parameter Estimation User Manual Part I, Watermark Numerical Computing, Brisbane, Australia, available at: http://www.pesthomepage.org/getfiles. php?file=newpestman2.pdf\&usg=AOvVaw0XsrKp9kwYUaX_ DkwULET9 (last access: 26 February 2018), 2016.

DSE: Victorian Aquifer Framework: Updates for Seamless Mapping of Aquifer Surfaces, available at: http://www.vvg.org.au/ cb_pages/files/207086.pdf (last access: 26 February 2018), 2012.

EcoDev: Victorian Winter Crop Summary 2015, Department of Economic Development, Jobs, Transport and Resources, Horsham, Victoria, Australia, available at: https://grdc.com.au/resources-and-publications/all-publications/ publications/2015/03/nvt-victorian-winter-crop-summary-2015 (last access: 26 February 2018), 2015.

Finger, L. and Morris, M.: Water Management Options: Assisting irrigators with Stream Flow Management Plan implementation, Department of Primary Industries (DPI), State of Victoria, Tatura, Victoria, available at: http://vro.agriculture.vic.gov.au/ dpi/vro/vrosite.nsf/0d08cd6930912d1e4a2567d2002579cb/ adbda16966d0e530ca2574c8002ccbfa/\$FILE/

WaterManagementOptionsReport_2005.pdf (last access: 22 March 2018), 2005.

Franzén, F., Kinell, G., Walve, J., Elmgren, R., and Söderqvis, T.: Participatory social-ecological modeling in eutrophication management: The case of Himmerfjärden, Sweden, Ecol. Soc., 16, 27, https://doi.org/10.5751/ES-04394-160427, 2011.

GM-W: Lake Eppalock Land and On-Water Management Plan, Tatura, Victoria, 2013.

GM-W: Campaspe Basin - Goulburn Murray Water, available at: https://www.g-mwater.com.au/water-resources/catchments/ gmwcatchments/campaspebasin (last access: 18 December 2017), 2017a.

GM-W: Lake Eppalock - Goulburn Murray Water, available at: https://www.g-mwater.com.au/water-resources/catchments/ storages/campaspe/lakeeppalock (last access: 18 December 2017), 2017b.

Hughes, L., Steffen, W., Rice, M., and Pearce, A.: Feeding a hungry nation: Climate change, food and farming in Australia, Climate Council of Australia Limited, Sydney, Australia, available at: https://www.climatecouncil.org.au/ uploads/7579c324216d1e76e8a50095aac45d66.pdf (last access: 26 February 2018), 2015.

Ivkovic, K. M., Croke, B. F. W., Kelly, R. A.: Overcoming the challenges of using a rainfall-runoff model to estimate the impacts of groundwater extraction on low flows in an ephemeral stream, Hydrol. Res., 45, 58-72, https://doi.org/10.2166/nh.2013.204, 2014.

Jakeman, A. J. and Letcher, R. A.: Integrated assessment and modelling: Features, principles and examples for catchment management, Environ. Modell. Softw., 18, 491-501, https://doi.org/10.1016/S1364-8152(03)00024-0, 2003.
Jakeman, A. J., Letcher, R. A., and Norton, J. P.: Ten iterative steps in development and evaluation of environmental models, Environ. Modell. Softw., 21, 602-614, https://doi.org/10.1016/j.envsoft.2006.01.004, 2006.

Kraft, P., Multsch, S., Vaché, K. B., Frede, H.-G., and Breuer, L.: Using Python as a coupling platform for integrated catchment models, Adv. Geosci., 27, 51-56, https://doi.org/10.5194/adgeo27-51-2010, 2010.

Krueger, T., Page, T., Hubacek, K., Smith, L., and Hiscock, K.: The role of expert opinion in environmental modelling, Environ. Modell. Softw., 36, 4-18, https://doi.org/10.1016/j.envsoft.2012.01.011, 2012.

Malard, J. J., Inam, A., Hassanzadeh, E., Adamowski, J., Tuy, H. A., and Melgar-Quiñonez, H.: Development of a software tool for rapid, reproducible, and stakeholder-friendly dynamic coupling of system dynamics and physicallybased models, Environ. Modell. Softw., 96, 410-420, https://doi.org/10.1016/J.ENVSOFT.2017.06.053, 2017.

McKay, J.: Water instititional reforms in Australia, Water Policy, 7, 35-52, https://doi.org/10.1080/02508069908692147, 2005.

MDBA: Sustainable Rivers Audit 2: The ecological health of rivers in the Murray-Darling Basin at the end of the Millennium Drought (2008-2010), Summary, available at: https://www.mdba.gov.au/sites/default/files/pubs/ SRA2-SUMMARY-FINAL_0.pdf (last access: 26 February 2018), 2012.

MDBA: Campaspe/Murray-Darling Basin Authority, available at: https://www.mdba.gov.au/discover-basin/catchments/campaspe (last access: 18 December 2017), 2017.

NCCMA: The North Central CMA Region Environmental Water Management Plan for the Campaspe River System, available at: http://www.vewh.vic.gov.au/_data/assets/pdf_file/0004/ 368698/Campaspe-River-EWMP-FINAL.pdf (last access: 26 February 2018), 2014a.

NCCMA: Campaspe River resource Guide, available at: http://www.nccma.vic.gov.au/sites/default/files/publications/ campaspe_river_resource_guide.pdf (last access: 26 February 2018), 2014b.

Niswonger, R. G., Panday, S., and Ibaraki, M.: MODFLOW-NWT, A Newton Formulation for MODFLOW-2005, in: Section A, Groundwater; Book 6 Modeling Techniques (p. 44), available at: https://pubs.usgs.gov/tm/tm6a37/pdf/tm6a37.pdf (last access: 26 February 2018), 2011.

NVIRP: Majority of Campaspe irrigators to exit permanently, available at: http://www.g-mwater.com.au/downloads/gmw/ connections/Communication/Media/MediaReleases2010/ Majority_of_Campaspe_irrigators_to_exit_permanently.pdf (last access: 26 February 2018), 2010.

NVIRP: NVIRP Annual Report 2010-2011, Northern Victoria Irrigation Renewal Project (NVIRP), Victoria, Australia, 2011.

Sletholt, M. T., Hannay, J. E., Pfahl, D., and Langtangen, H. P.: What do we know about scientific software development's agile practices?, 24-36, https://doi.org/10.4324/9780203894644, London, Routledge, 2012.

State of Victoria: NVIRP Stage 2 On Farm Project.pdf, State of Victoria, Northern Victoria Irrigation Renewal Project: On Farm Priority Project, available at: http://www.agriculture.gov.au/ SiteCollectionDocuments/water/vic-farm-project.pdf (last access: 1 March 2018), 2011. 
Tennakoon, S., Richards, D., Milroy, S., and Harris, G.: Water use efficiency in the Australian cotton industry, in: Waterpak: A Guide for Irrigation Management in Cotton and Grain Farming Systems, edited by: Wiggington, D., 22-27, Cotton Research and Development Corporation, 2013.

Ticehurst, J. and Curtis, A.: Improving on-farm water use efficiency amongst irrigators in the Campaspe River system and the Rochester Irrigation Area, Wagga Wagga, NSW, 2650, Australia, 2016.

Ticehurst, J. and Curtis, A.: Preliminary assessment of conjunctive use opportunities for in the Murray Darling Basin: a case study in the lower Campaspe catchment, Wagga Wagga, NSW, 2650, Charles Sturt University, 2017.

Van Dijk, A. I. J. M., Beck, H. E., Crosbie, R. S., De Jeu, R. A. M., Liu, Y. Y., Podger, G. M., Timbal, B., and Viney, N. R.: The Millennium Drought in southeast Australia (2001-2009): Natural and human causes and implications for water resources, ecosystems, economy, and society, Water Resour. Res., 49, 1040-1057, https://doi.org/10.1002/wrcr.20123, 2013.
Vaze, J., Teng, J., and Chiew, F. H. S.: Assessment of GCM simulations of annual and seasonal rainfall and daily rainfall distribution across south-east Australia, Hydrol. Process., 25, 14861497, https://doi.org/10.1002/hyp.7916, 2011.

Voinov, A. and Gaddis, E. J. B.: Lessons for successful participatory watershed modeling: A perspective from modeling practitioners, Ecol. Model., 216, 197-207, https://doi.org/10.1016/j.ecolmodel.2008.03.010, 2008.

Wheeler, S. A. and Cheeseman, J.: Key Findings from a Survey of Sellers to the Restoring the Balance Programme, Economic Papers, 32, 340-352, https://doi.org/10.1111/1759-3441.12038, 2013. 